\title{
Deteksi Komentar Cyberbullying Pada Media Sosial Berbahasa Inggris Menggunakan Naïve Bayes Classification
}

\author{
Jasman Pardede ${ }^{1}$, Yusup Miftahuddin², Wahidul Kahar ${ }^{3}$ \\ 1,2Jurusan Teknik Informatika, Fakultas Teknologi Industri, Institut Teknologi Nasional, Bandung \\ JI.PH.H. Mustofa No.23 Bandung 40124, Indonesia \\ e-mail: 1jasman@itenas.ac.id, ${ }^{2}$ ymiftahuddin@gmail.com, ${ }^{3}$ wahidulkahar96@gmail.com
}

\begin{abstract}
Abstrak
Pesatnya perkembangan teknologi dan media sosial dapat memudahkan pengguna untuk menyampaikan informasi. Selain itu, media sosial juga memberikan dampak negatif dengan cara memposting tulisan kejam atau berkomentar semena-mena tanpa memikirkan akibat pada orang lain. Hal inilah yang menjadikan salah satu terjadinya tindak kekerasan dalam dunia maya (Cyberbullying). Tahapan awal yang dilakukan dalam penelitian ini adalah pengolahan bahasa atau yang disebut dengan text preprocessing meliputi tokenizing, casefolding, stopword removal dan stemming. Kemudian feature selection yaitu mengubah dokument teks menjadi matriks dengan tujuan untuk mendapatkan fitur pada setiap kata untuk dijadikan parameter atau kriteria klasifikasi. Untuk pengambilan keputusan apakah komentar mengandung makna bully atau nonbully menggunakan algoritma Nä̈ve Bayes Classification dengan model multinomial naïve bayes. Perhitungan yang dilakukan adalah menghitung nilai probabilitas setiap kata yang muncul berdasarkan class dan nilai perkalian class conditional probability. Berdasarkan hasil eksperimen menggunakan dataset "cyberbullying comments" yang diambil dari Kaggle akurasi yang didapat sebesar $80 \%$, precission $81 \%$ dan recall $80 \%$.
\end{abstract}

Kata kunci: Cyberbullying, Feature Selection, Naïve Bayes Classification

\begin{abstract}
The rapid development of technology and social media can facilitate users to convey information. Besides, social media also has a negative impact by posting cruel posts or commenting arbitrarily without thinking about the consequences on others. This is what makes one of the acts of violence in cyberspace (Cyberbullying). The initial stages carried out in this research are language processing or what is called text preprocessing including tokenizing, case-folding, stopword removal and stemming. Then the feature selection is to change the text document into a matrix to get the features of each word to be used as a parameter or classification criteria. For decision making whether comments contain bully or non-bully meaning using the Naïve Bayes Classification algorithm with the multinomial naïve Bayes model. The calculation is done is to calculate the probability value of each word that appears based on the class and the value of the class conditional probability multiplication. Based on the results of experiments using the dataset "cyberbullying comments" taken from Kaggle obtained $80 \%$ accuracy, $81 \%$ precision and $80 \%$ recall.
\end{abstract}

Keywords: Cyberbullying, Feature Selection, Naïve Bayes Classification

\section{Pendahuluan}

Deteksi dalam kamus Kamus Bahasa

Besar Bahasa Indonesia (KBBI) adalah usaha menemukan dan menentukan keberadaan, anggapan, atau kenyataan. Deteksi juga meruapakan suatu proses untuk memeriksa atau melakukan pemeriksaan kembali terhadap sesuatu dengan menggunakan cara dan metode teknik tertentu.

Media sosial salah satu sebagai cara berkomunikasi yang efisien, nyaman, dan populer (Barlett, Gentile, Chng, Li, \& Chamberlin, 2018). Contoh media sosial, 
menurut (Carr \& Hayes, 2015) termasuk situs web jejaring sosial Facebook, blogging, Tinder, Instagram, Yik Yak, dan lainnya. Sosial media biasanya digunakan oleh seseorang sebagai media komunikasi, sarana informasi dan sebagai media hiburan bagi penggunanya (Nasution \& Hayaty, 2019). Perkembangan teknologi informasi, internet, dan media sosial memberikan dampak perubahan kepada perilaku manusia dalam bersosial dan berkomunikasi (Rifauddin, 2016).

Berdasarkan hasil riset Wearesosial Hootsuite yang dirilis Januari 2019 pengguna media sosial di Indonesia mencapai 150 juta atau sebesar $56 \%$ dari total populasi. Jumlah tersebut naik $20 \%$ dari survei sebelumnya. Sementara pengguna media sosial mobile (gadget) mencapai 130 juta atau sekitar $48 \%$ dari populasi. Besarnya populasi, pesatnya pertumbuhan pengguna internet dan telepon merupakan potensi bagi ekonomi digital nasional (databoks.katadata.co.id, 2019). Sebagai contoh penggunaan media sosial yang positif adalah memudahkan pengguna untuk menyebarkan informasi atau pengetahuan di seluruh dunia (Wijanto 2015). Namun, media sosial juga memberikan dampak negatif seperti memposting tulisan kejam ataupun mengunggah foto yang berhubungan dengan individu lain dengan tujuan mengintimidasi dan merusak nama baik korban sehingga korban merasa tersakiti dan malu (Nasrullah, 2015). Hal inilah salah satu faktor yang menyebabkan adanya cyberbullying (Rifauddin, 2016). Salah satu dampak negatif yang muncul dari banyaknya pengguna jejaring sosial menimbulkan adanya cyberbullying (Barlett, Gentile, Chng, Li, \& Chamberlin, 2018).

Cyberbullying merupakan perilaku seseorang atau kelompok secara sengaja dan berulang kali melakukan tindakan yang menyakiti orang lain melalui komputer, telepon seluler, dan alat elektronik lainnya (Rifauddin, 2016). Cyberbullying biasanya didefinisikan sebagai penyerangan yang sengaja dan berulang kali dilakukan secara elektronik konteks (misalnya, e-mail, blog, pesan instan, dan pesan teks) terhadap orang yang tidak dapat dengan mudah membela diri atau dirinya sendiri (Tian, Yan, \& Huebner, 2018). Cyberbullying sebagai tindakan atau perilaku agresif dengan menggunakan elektronik terhadap suatu kelompok atau individu tertentu yang dilakukan secara berulang kali dan seiring waktu, secara online didunia internet (Nilan, Burgess, Hobbs, Threadgold, \& Alexander, 2015). Cyberbullying adalah tindakan mengintimidasi menggunakan elektronik, seperti pesan instan, email, ruang obrolan, situs web, game online, situs jejaring sosial, dan pesan teks (Hase, Goldberg, Smith, Stuck, \& Campain, 2015). Walaupun tidak bertemu secara langsung tatap muka (face to face) tindakan cyberbullying juga bisa memakan korban karena tidak ada larangan sedikitpun bagi orang berkomentar pada kolom komentar (Natalia, 2016). Memposting tulisan kejam ataupun mengunggah foto yang berhubungan dengan individu lain dengan tujuan mengintimidasi dan merusak nama baik korban sehingga korban merasa tersakiti dan malu (Nasrullah, 2015). Hal inilah salah satu faktor yang menyebabkan adanya cyberbullying (Rifauddin, 2016).

Untuk mengatahui suatu teks komentar mengandung makna bully atau tidak, metode yang diusulkan adalah naïve bayes classification dengan model multinomial naïve bayes. Naive bayes banyak digunakan dalam klasifikasi teks dan memiliki beberapa kelebihan yang mudah diterapkan dan memiliki kinerja yang baik dalam klasifikasi teks (Santoso, Yuniarno, \& Hariadi, 2015 ). Pendekatan supervised machine learning (ML) banyak digunakan untuk klasifikasi teks. Algoritma pembelajaran mesin yang paling populer termasuk Naïve Bayes (NB) (Al-Anzi \& AbuZeina , 2017). Klasifikasi dalam pengambilan informasi dan klasifikasi teks paling terkenal adalah klasifikasi naif Bayes (NB) yang telah terbukti sangat efektif pada banyak aplikasi data nyata (Feng, Guo, Jing, \& Sun, 2015). Naive Bayes (NB) adalah salah satu dari 10 algoritma teratas berkat kesederhanaannya, efisiensi, dan interpretabilitas untuk melemahkan asumsi independensi atributnya. (Wang, Jiang, \& $\mathrm{Li}$, 2015). Klasifikasi Naïve Bayes merupakan penggolong probabilistik berdasarkan Teorema Bayes (Rasjid \& Setiawan, 2017).

Multinomial Naive Bayes (MNB) adalah variasi dari Naive Bayes yang dirancang untuk menyelesaikan klasifikasi dokumen teks dengan menghitung jumlah kemunculan kata atau bobot kata sebagai fitur klasifikasi (Pratama \& Sarno, 2015). Dengan menerapkan pendektaan machine learning pada klasifikasi sebuah dokumen 
teks serta meningkatkan akurasi klasifikasi teks adalah Multinomial Naive Bayes (MNB) (Wang, Jiang, \& Li, 2015).

\section{Metode Penelitian \\ Rancangan Sistem}

Rancangan sistem yang akan dibangun dalam penelitian terbagi menjadi beberapa bagian diantaranya preprocessing, feature selection, dan classification. Gambar 1 memperlihatkan sistem yang dibangun secara lebih rinci. Bagian sistem yang berinteraksi dengan pengguna aplikasi secara langsung dimana pengguna (user) akan memasukkan teks komentar sebagai inputan. Teks komentar memberikan hasil berupa komentar yang mengandung bully atau nonbully. Selain itu juga, dapat diketahui bahwa inputan teks yang dicari tentang komentar bersifat negatif (bully) dan positif (nonbully).

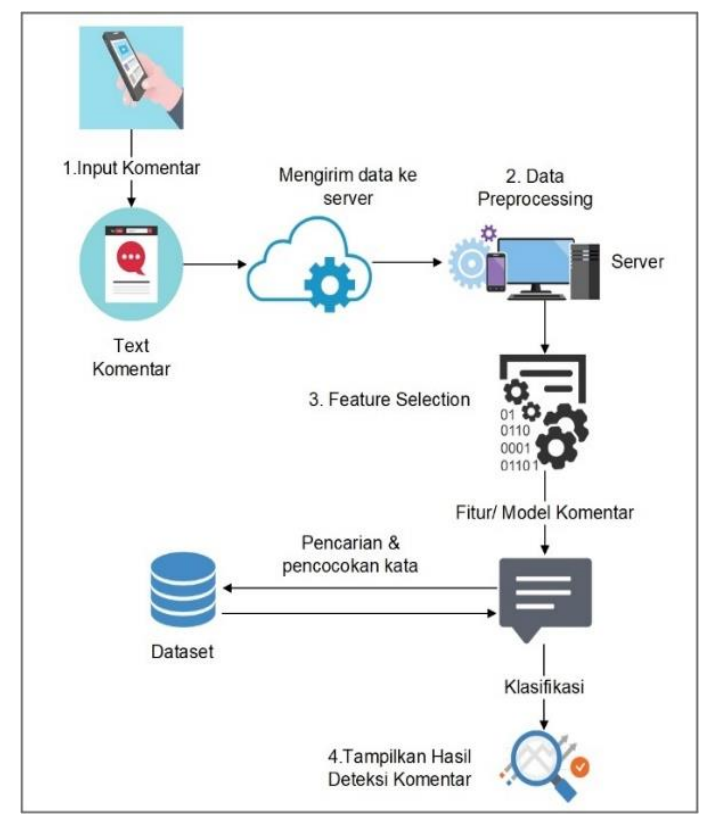

Gambar 1. Rancangan Sistem Deteksi Komentar Cyberbullying Pada Media Sosial

Berikut ini merupakan penjelasan dari rangkaian sistem secara keseluruhan yang dibangun. Terdapat 4 (empat) langkah dalam melakukan deteksi komentar cyberbullying pada media sosial bahasa Ingris, yaitu:

1. Langkah pertama yang dilakukan adalah memasukkan kalimat komentar dalam bentuk text komentar.

2. Kemudian pengolahan data komentar atau disebut dengan Data Preprocessing adalah pengolahan bahasa yang tidak terstruktur menjadi lebih terstruktur.

3. Feature selectioan adalah proses ekstraksi data dokumen teks menjadi matriks dengan tujuan mendapatkan fitur setiap kata yang muncul.

4. Langkah terakhir melakukan pendeteksian atau pengambilan keputusan terhadap teks komentar yang telah dimasukkan sebelumnya. Metode klasifikasi yang digunakan naïve bayes classification dengan menggunakan model multinomial naïve bayes. Hasil output berupa deteksi komentar bully atau nonbully berdasarkan nilai probabilitas tertinggi.

\section{Preprocessing}

Text Preprocessing adalah tahap awal dari teks mining untuk merubah data yang tidak terstruktur menjadi data terstruktur (Kurniawan, Fauzi, \& Widodo, 2017). Tujuan lain juga untuk menghilangkan noise yang terdapat pada dokumen teks dan mengambil fitur atau parameter penting pada dokumen teks.

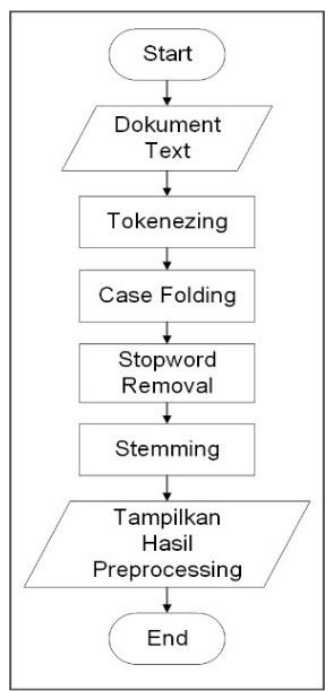

Gambar 2. Tahap Pre-processing Secara Umum

Pada Gambar 2 menunjukan tahapan pengolahan teks komentar dimulai dari inputan sebuah dokumen text, lalu akan dilakukan tokenizing, case-folding, stopword removal dan stemming biasanya proses ini disebut dengan text preprocessing yang nantinya akan diteruskan proses selanjutnya. Text pre-processing juga dapat membantu dalam pengambilan keputusan secara baik berdasarkan pengolahan yang sudah dilakukan 
sebelumnya, dengan tahapan sabagai berikut:

- Tokenizing adalah adalah memotong urutan karakter menjadi potonganpotongan, yang disebut token, dan pada saat yang sama mungkin membuang karakter tertentu, seperti tanda baca dan selain angka (Hasanah, Astuti, Wahyudi, Rifai, \& Pambudi , 2018).

- Case-folding adalah mengubah semua huruf menjadi huruf kecil (Hasanah, Astuti, Wahyudi, Rifai, \& Pambudi, 2018).

- Stopword Removal adalah menghapus kata-kata yang tidak berguna (Alkhurayji \& Sameh, 2017).

- Stemming adalah megubah kata ke dalam bentuk kata dasar (root word) dengan menghilangkan aditif yang ada. Algoritma stemming yang digunakan adalah Porter Stemmer untuk bahasa Inggris (Pratama \& Sarno, 2015).

Secara khusus porter stemmer memiliki lima langkah dengan menerapkan aturan disetiap langkah (Ali \& Ibrahim, 2015) sebagai berikut:

1) Step 1

Menghilangkan beberapa imbuhan dalam bentuk bentuk past tense dan jamak dari kalimat murni. Dengan 3 tahapan sebagai berikut:

a) Step $1 a$

SSES->SS

caresses -> caress

b) Step $1 b$

$\left({ }^{*} v^{*}\right)$ ING-> opening $\rightarrow$ agree

c) Step $1 \mathrm{C}$

$\left({ }^{*} v^{*}\right) Y->1$

history -> histori

2) Step 2

Selanjutnya adalah pencocokan pola pada beberapa akhiran umum. Dengan menghapus derivasi (menghasilkan katakata yang berbeda dari paradigma yang berbeda) akhiran ( $d$-sufiks) dan mengikuti aturan sebagai berikut:

$m>0)$ ATIONAL $->$ ATE

relational $->$ relate

3) Step 3

Menghilangkan akhiran kata special dan juga menghilangkan derivasi sufiks. Kemudian gabungan dari derivasi sufiks dihilangkan menjadi single derivasi sufiks.
Lalu jika akhiran -icational, pada step 2 direduksi menjadi -icate dan pada step ini direduksi menjadi -ic. Di bawah adalah contoh aturan yang diterapkan pada Langkah 3.

$m>0$ )NESS->

possibleness -> possible

4) Step 4

Pada step 4 adalah menghilangkan sufiks lain pada gabungan kata seperti -ic, able, -ive dan masih banyak yang lain. Contoh aturan yang terlibat dalam langkah ini adalah sebagai ditunjukkan di bawah ini

$(m>1)$ MENT->

adjustment $->$ adjust

5) Step 5

Langkah terakhir adalah merapikan algoritma setelah menghapus sufiks pada langkah-langkah sebelumnya. Kemudian cek apakah akhiran berbentuk huruf vokal jika ada diperbaiki dengan tepat. Tahapan ini terdiri dari 2 tahapan sebagai berikut:
a) Step $5 a$
$\mathrm{m}>1) \mathrm{E}$
probate -> probat
b) Step $5 b$
$\mathrm{m}>1$ and ${ }^{*} \mathrm{~d}$ and ${ }^{*} \mathrm{~L}$ )-> single letter
bill $\rightarrow$ bil

\section{Feature Selection}

Tabel 1. Cotoh Hasil Ekstraksi Fitur Pada Dokument Teks

\begin{tabular}{|c|c|c|c|c|c|c|c|c|}
\hline Text & This & is & a & nice & hotel & not & all & at \\
\hline $\begin{array}{c}\text { This } \\
\text { is a } \\
\text { nice } \\
\text { hotel }\end{array}$ & 1 & 1 & 1 & 1 & 1 & 0 & 0 & 0 \\
\hline $\begin{array}{c}\text { Not } \\
\text { a } \\
\text { nice } \\
\text { hotel } \\
\text { at all }\end{array}$ & 0 & 0 & 1 & 1 & 1 & 1 & 1 & 1 \\
\hline
\end{tabular}

Feature selection adalah proses ekstraksi data pada dokumen teks untuk mendapatkan fitur setiap kata yang muncul sebagai kriteria klasifikasi. Salah satu teknik ektraksi fitur dalam sebuah teks dokument adalah Bag-of-words dimana fitur terdiri ini dari individu atau kelompok kata yang ditemukan dalam teks (Etaiwi \& Naymat, 2017). Proses ini menghasilkan nilai numerical vector dari tiap teks yang 
diteruskan ke proses training tiap algoritma klasifikasi (Sastrodikoro W., Palit, \& Justinus Andjarwirawan, 2018). Contoh fitur Bag-of-words ditunjukkan pada Tabel 1, dimana setiap kemunculan kata dalam ulasan akan diwakili oleh frekuensi kemunculan kata dalam teks. (Etaiwi \& Naymat, 2017).

\section{Naïve Bayes Classification}

Metode Naïve Bayes merupakan metode yang memanfaatkan metode probabilitas dan statistik yang dikemukakan oleh ilmuwan Inggris Thomas Bayes (Susanto \& Indriyani, 2019). Naive Bayes adalah algoritma klasifikasi berdasarkan teorema Bayes (Pratama \& Sarno, 2015). Naïve Bayes (NB) adalah model pembelajaran statistik berbasis probabilitas dan memiliki asumsi premis bahwa semua atribut sepenuhnya independen pada nilai variabel kelas (Wang, Jiang, \& Li, 2015). Teorema Bayes mengasumsikan bahwa semua variabel independen mempertimbangkan nilai variabel kelas (Saritas \& Yasar, 2019). Algoritma Naive Bayes Classifier merupakan pengklasifikasian dengan metode probabilitas, yaitu memprediksi peluang di masa depan berdasarkan pengalaman di masa sebelumnya sehingga dikenal sebagai teorema Bayes (Nugroho, 2018).

$$
\boldsymbol{P}(\boldsymbol{A} \mid \boldsymbol{B}) \frac{\boldsymbol{P}(\boldsymbol{A}) \boldsymbol{P}(\boldsymbol{B} \mid \boldsymbol{A})}{\boldsymbol{P}(\boldsymbol{B})}
$$

dimana:

$\boldsymbol{P}(\boldsymbol{A} \mid \boldsymbol{B})=$ peluang terjadinya $\mathrm{A}$ dengan syarat $B$ terjadi lebih dahulu

$\boldsymbol{P}(\boldsymbol{A})=$ Peluang kemunculan $\mathrm{A}$

$\boldsymbol{P}(\boldsymbol{B} \mid \boldsymbol{A})=$ peluang terjadinya $\mathrm{B}$ dengan syarat $A$ terjadi lebih dahulu

$P(B)=$ Peluang kemunculan $B$

\section{Multinomial Bayes Classification}

Multinomial naïve Bayes (MNB) menangkap frekuensi yang terjadi pada semua kata dalam dokumen (Wang, Jiang, \& Li, 2015). Multinomial Naïve Bayes tidak jauh berbeda dengan NBC yaitu perhitungan prior, conditional dan posterior akan tetapi untuk conditional probability terdapat perubahan (Pujadayanti, Fauzi, \& Sari, 2018).

$$
\mathbf{P}\left(\mathbf{w}_{\mathbf{i}} \mid \mathbf{c}_{\mathbf{j}}\right)=\frac{\operatorname{Count}\left(\mathbf{w}_{\mathbf{i}}, \mathbf{c}_{\mathbf{j}}\right)+\mathbf{1}}{\sum_{\mathbf{w} \in \mathbf{V}}\left(\operatorname{count}\left(\mathbf{w}, \mathbf{c}_{\mathbf{j}}\right)\right)+\mathbf{1}}
$$

$$
=\frac{\operatorname{Count}\left(\mathbf{w}_{\mathbf{i}}, \mathbf{c}_{\mathbf{j}}\right)+\mathbf{1}}{\sum_{\mathbf{w} \in \mathbf{V}}\left(\operatorname{count}\left(\mathbf{w}, \mathbf{c}_{\mathbf{j}}\right)\right)+|\mathbf{V}|}
$$

dimana:

$$
\boldsymbol{P}\left(\boldsymbol{w}_{\boldsymbol{i}} \mid \boldsymbol{c}_{\boldsymbol{j}}\right)=\text { Conditional Probability }
$$

$\operatorname{Count}\left(\boldsymbol{w}_{i}, \boldsymbol{c}\right)=$ menghitung jumlah kata $W i$ dengan $\boldsymbol{i}=1,2,3$.. $\mathrm{m}$ pada kelas $\mathrm{j}$ dengan $\mathrm{j}=$ $1,2,3, \ldots . n$

$\sum_{w \in V}(\operatorname{count}(\boldsymbol{w}, \boldsymbol{c}))=$ menghitung jumlah seluruh kata kelas $\mathrm{j}$

$|V|=$ menghitung kata unik pada seluruh dokumen

\section{Hasil dan Pembahasan \\ 1. Dataset}

Dataset yang digunakan merupakan dataset "cyber-bullying comments" yang diambil dari Kaggle, dimana 1313 komentar bully dan 1423 nonbully dengan total 2736 data komentar.

\section{Implementasi Sistem}

Implementasi sistem pada penelitian ini menggunakan bahasa pemrograman python, JetBrains PyCharm Community Edition dan PHP. Library yang digunakan adalah pandas (pembacaan file), nltk (pengolahan bahasa), PorterStemmer (stemming) dan scikit-learn (klasifikasi dan feature extraction). Setiap komentar diinputkan akan diuji satu persatu, kemudian diproses melalui service yang mengembalikan data dalam bentuk JSON.

\section{Pengujian Sistem Aplikasi}

Pada pengujian aplikasi adalah menguji secara fungsional pada setiap proses yang dilakukan oleh sistem. Adapun proses pengujian yang dilakaukan sebagai berikut.

\section{Text Preprocessing Proses Tokenizing}

Pada proses tokenizing merupakan pemecahan kalimat menjadi kata (token) dengan fungsi split kemudian menghapus tanda baca, huruf, emoji dan selain angka.

Pengguna (user) akan memasukkan komentar kemudian klik tombol proses, maka sistem akan menampilkan hasil tokenizing dan untuk melanjutkan ke proses selanjutnya dengan klik tombol next seperti yang terlihat pada Gambar 3. 


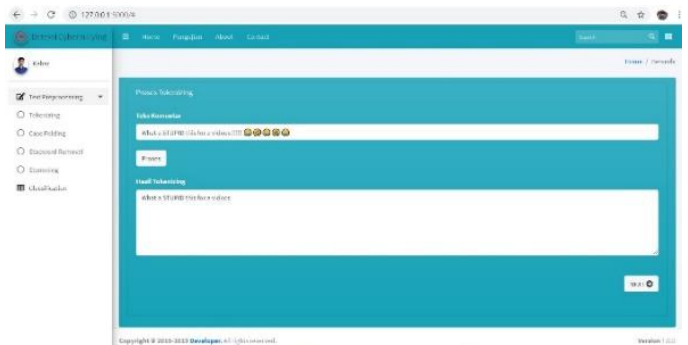

Gambar 3. Proses Tokenizing

\section{Proses Case-folding}

Proses case-folding merupakan lanjutan dari tahap text pre-processing dengan tujuan merubah teks dari huruf kapital menjadi huruf kecil seperti pada Gambar 4.

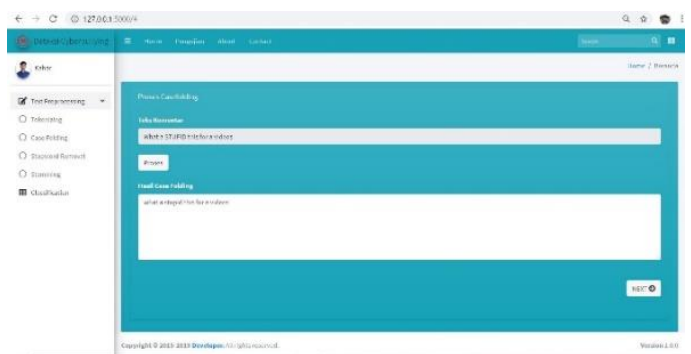

Gambar 4. Proses Casefolding

\section{Proses Stopword Removal}

Stopword Removal merupakan lanjutan dari tahap text pre-processing dengan tujuan menghilangkn kata-kata yang tidak penting dalam penggunaan bahasa Inggris. Adapun proses stopword removal ditunjukkan pada Gambar 5.

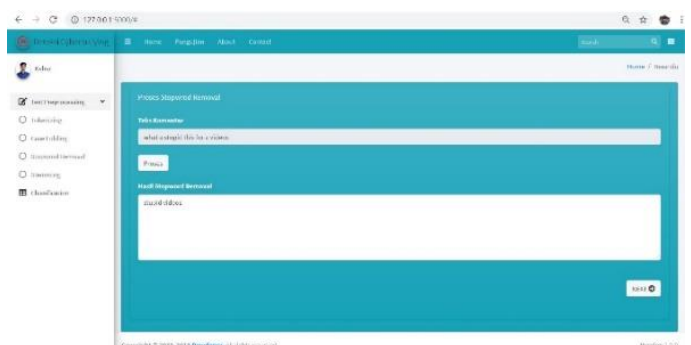

Gambar 5. Proses Stopword Removal

\section{Proses Stemming}

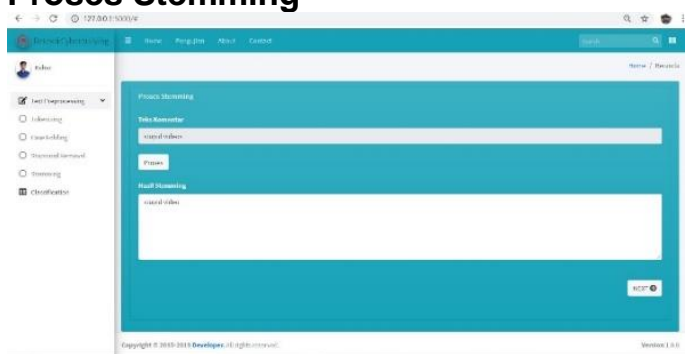

Gambar 6. Proses Stemming
Pada proses stemming merupakan proses terakhir dalam text pre-processing dimana proses stemming adalah mengubah kata ke dalam bentuk kata dasar (stem) seperti pada Gambar 6.

\section{Feature Selection}

Pada proses feature selection, hasil dari pre-processing yaitu teks komentar dalam bentuk kata, dimana sistem mengkonversi teks tersebut kedalam bentuk numerical vector (matriks) untuk mendapatkan fitur pada setiap kata dan dijadikan sebagai kriteria klasifikasi. Adapun contoh hasil ekstraksi fitur pada teks dapat dilihat pada Gambar 7.

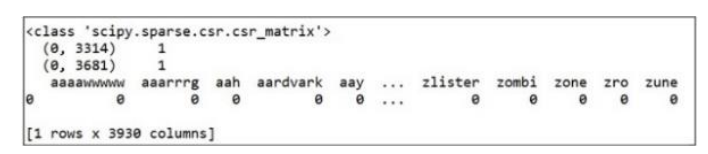

Gambar 7. Hasil Feature Extraction

Pada Gambar 7 merupakan hasil feature selection, dimana fungsi "scipy.parse" adalah mengubah dokumen teks menjadi matriks, kemudian untuk mendapatkan fitur pada setiap kata dengan menerapkan teknik bag of word, seperti dari kata "aaaawwwww" sampai dengan "zune". Dimana nilai 0 bila kata tersebut tidak muncul pada dokument teks dan 1 bila muncul.

\section{Proses Klasifikasi}

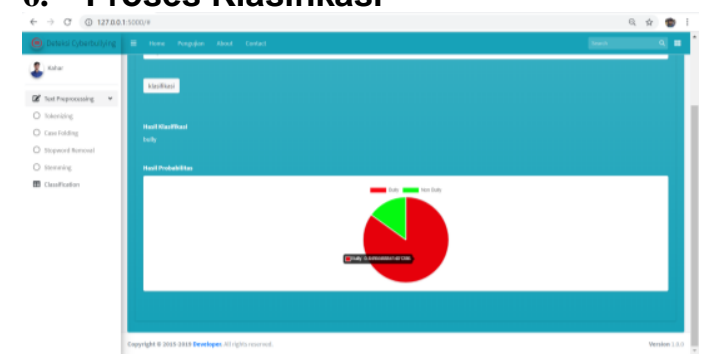

Gambar 8. Proses Hasil Deteksi Komentar

Proses klasifikasi adalah menentukan apakah komentar yang dideteksi mengandung makna bully atau nonbully seperti yang terlihat pada Gambar 8. Dengan menggunakan algoritma naïve bayes model Multinomial Naïve Bayes. Jika nilai probabilitas bully (warna merah) menunjukkan lebih tinggi dibandingkan dengan nilai probabilitas nonbully (warna hijau), maka komentar tersebut dikategorikan komentar bully dan sebaliknya dikategorikan nonbully. Adapun 
hasil dari pengujian pada 10 komentar dapat dilihat pada Tabel 2.

Tabel 2. Hasil Pengujian Terhadap 10 komentar

\begin{tabular}{|c|c|c|c|}
\hline No & Komentar & Kategori & Terdeteksi \\
\hline 1. & $\begin{array}{c}\text { Why I love joker } \\
\text { more than } \\
\text { Batman. }\end{array}$ & Nonbully & Nonbully \\
\hline 2. & $\begin{array}{c}\text { This is literally } \\
\text { her best song to } \\
\text { date }\end{array}$ & Nonbully & Nonbully \\
\hline 3. & $\begin{array}{l}\text { I immediately } \\
\text { fell in love with } \\
\text { this song when I } \\
\text { first heard it }\end{array}$ & Nonbully & Nonbully \\
\hline 4. & $\begin{array}{c}\text { 2019! Best } \\
\text { movie :Joker } \\
\text { Like if u agree } \\
\text { (:) }\end{array}$ & Nonbully & Nonbully \\
\hline 5. & $\begin{array}{l}\text { I didn't know } \\
\text { joker has sad } \\
\text { life }\end{array}$ & Nonbully & Bully \\
\hline 6. & $\begin{array}{c}\text { after watching } \\
\text { this I realized } \\
\text { that joker have } \\
\text { a bad and sad } \\
\text { memories }\end{array}$ & Bully & Bully \\
\hline 7. & $\begin{array}{l}\text { What a stupid } \\
\text { title for a video. }\end{array}$ & Bully & Bully \\
\hline 8. & $\begin{array}{c}\text { That is the most } \\
\text { STUPID } \\
\text { question I've } \\
\text { heard in a while! } \\
\text { S }\end{array}$ & Bully & Bully \\
\hline 9. & $\begin{array}{c}\text { Nigeria is a } \\
\text { corrupt and } \\
\text { hateful place. } \\
\text { Prejudice is } \\
\text { based on } \\
\text { ignorance and } \\
\text { stupidity. }\end{array}$ & Bully & Bully \\
\hline 10. & $\begin{array}{c}\text { Google Moy } \\
\text { Park. Sky } \\
\text { News Chicken } \\
\text { Liars! }\end{array}$ & Bully & Nonbully \\
\hline
\end{tabular}

Berdasarkan hasil pengujian terhadap 10 komentar terdapat beberapa kesalahan dalam pengujian diantara pada komentar ke-5 dengan kategori nonbully, namun sistem mendeteksi komentar tersebut bully dan pada komentar ke-10 dengan kategori bully, sistem mendeteksi nonbully. Dengan begitu dapat dihitung nilai accuracy, precision dan recall sesuai data komentar yang di uji.

\section{Pengujian accuracy, precision, recall dan f1-score metode naïve bayes classification}

Mengukur kinerja algoritma Naïve Bayes Classification menggunakan confusion matrix diamana akan mengukur kinerja sistem secara keseluruhan meliputi nilai accuracy, precision, recall dan f1score. Nilai accuracy, precision, recall, dan f1-score dapat dihitung dengan menggunakan persamaan berikut (Pardede, Jasman, \& Husada, M.G., 2016):

Accuracy $=\frac{T P+T N}{T P+F P+F N+T N}$

Precision $=\frac{T P}{T P+F P}$

Recall $=\frac{T P}{T P+F N}$

F Measure $=2 *\left(\frac{\text { Precision } * \text { Recall }}{\text { Precision }+ \text { Recall }}\right)$

dimana:

TP $=$ True Positive

$\mathrm{FP}=$ False Positive

$\mathrm{FN}=$ False Negative

$\mathrm{TN}=$ True Negative

Dalam kasus penelitian ini dataset yang digunakan yaitu 2736 data komentar akan terbagi menjadi 2 bagian diantaranya data training dan data testing dengan rasio $80 \%$ digunakan sebagai data training dan $20 \%$ sebagai data testing. Adapun hasil pengujian kinerja sistem dengan confusion matrix dapat dilihat pada Tabel 3.

Tabel 3. Hasil Perhitungan Recall, Precision dan F1-score

\begin{tabular}{|c|c|c|c|}
\hline Class & Precision & recall & F1-score \\
\hline Bully & 0.83 & 0.75 & 0.79 \\
\hline $\begin{array}{l}\text { Non } \\
\text { bully }\end{array}$ & 0.78 & 0.86 & 0.82 \\
\hline avg & 0.81 & 0.80 & 0.80 \\
\hline
\end{tabular}

Berdasarkan hasil pengujian kinerja pada Tabel 3. Nilai precision adalah berapa persen komentar yang benar bully dari keseluruhan komentar yang di prediksi bully, kemudian recall adalah berapa persen komentar yang di prediksi bully di bandingkan dengan keseluruhan komentar yang sebenarnya bully dan f1-score adalah perbandingan rata-rata precision dan recall yang dibobotkan.

\section{Kesimpulan}

Penelitian ini telah berhasil membagun model untuk mendeteksi deteksi komentar cyberbullying 
berdasarkan teks dan kategori menggunakan Naïve Bayes Classification. Hasil pengujian kinerja terhadap metode yang digunakan diperoleh akurasi sebesar $80 \%$ dengan nilai rata-rata menghasilkan precision $81 \%$, recall $80 \%$ dan 11 -score $80 \%$.

\section{Referensi}

Al-Anzi, F. S., \& AbuZeina, D. (2017). Towards an Enhanced Arabic Text Classification Using Cosine Similarity and Latent Semantic Indexing . Journal of King Saud University - Computer and Information Sciences , 189-195.

Ali, N. H., \& Ibrahim, N. S. (2015). Porter Stemming Algorithm for Semantic Checking. Computer Science Department, 253-258.

Al-khurayji, R., \& Sameh, A. (2017). AN EFFECTIVE ARABIC TEXT CLASSIFICATION APPROACH BASED ON KERNEL NAIVE BAYES CLASSIFIER. International Journal of Artificial Intelligence and Applications (IJAIA), Vol.8 1-10.

Barlett, C. P., Gentile, D. A., Chng, G., Li, D., \& Chamberlin, K. (2018). Social Media Use and Cyberbullying Perpetration: A Longitudinal Analysis. Violence and Gender, 17.

Carr, C. T., \& Hayes, R. A. (2015). Social Media: Defining, Developing, and Divining . Atlantic Journal of Communication, 1-43.

databoks.katadata.co.id. (2019, November 12). Retrieved from databoks.katadata.co.id: https://databoks.katadata.co.id/data publish/2019/02/08/berapapengguna-media-sosialindonesia\#: :targetText=Berdasark an\%20hasil\%20riset\%20Wearesosi al\%20Hootsuite,atau\%20sekitar\%2 048\%25\%20dari\%20populasi.

Etaiwi, W., \& Naymat, G. (2017). The Impact of applying Different Preprocessing Steps on Review Spam Detection. Procedia Computer Science, 273-279.

Feng, G., Guo, J., Jing, B.-Y., \& Sun, T. (2015). Feature Subset Selection Using Naive Bayes for Text Classification. Pattern Recognition Letters, 1-8.
Hasanah, U., Astuti, T., Wahyudi, R., Rifai, Z., \& Pambudi , R. A. (2018). An Experimental Study of Text Preprocessing Techniques for Automatic Short Answer Grading in Indonesian. IEEE 2018 3rd International Conference on Information Technology, Information System and Electrical Engineering (ICITISEE) Yogyakarta, Indonesia (pp. 23023). Yogyakarta, Indonesia: Information System and Electrical Engineering (ICITISEE).

Hase, C. N., Goldberg, S. B., Smith, D., Stuck, A., \& Campain, J. (2015). Impacts Of Traditional Bullying And Cyberbullying On The Mental Health Of Middle School And High School Students. Psychology in the Schools, 607-617.

Kurniawan, B., Fauzi, M. A., \& Widodo, A. W. (2017). Klasifikasi Berita Twitter Menggunakan Metode Improved Naïve Bayes. Jurnal Pengembangan Teknologi Informasi dan IImu Komputer, 1193-1200.

Nasrullah, R. (2015). PERUNDUNGAN SIBER (CYBER-BULLYING) DI STATUS FACEBOOK. Jurnal Sosioteknologi , 1-11.

Nasution, M. R., \& Hayaty, M. (2019). Perbandingan Akurasi dan Waktu Proses Algoritma K-NN dan SVM dalam Analisis Sentimen Twitter. JURNAL INFORMATIKA, 226-235.

Natalia, E. C. (2016). REMAJA, MEDIA SOSIAL DAN CYBERBULLYING. Jurnal Ilmiah Komunikasi , 119139.

Nilan, P., Burgess, H., Hobbs, M., Threadgold, S., \& Alexander, W. (2015). Youth, Social Media, and Cyberbullying Among Australian Youth: "Sick Friends". Social Media + Society, 1-12.

Nugroho, A. (2018). Analisis Sentimen Pada Media Sosial Twitter Menggunakan Naive Bayes Classifier Dengan Ekstrasi Fitur NGram. Jurnal Sains Komputer \& Informatika (J-SAKTI), Volume (2) No.2 September 2018, pp. 200209.

Pardede, Jasman, \& Husada, M.G. (2016). Comparison of VSM, GVSM, and LSI in Information Retrieval for 
Indonesian Text, Journal Teknologi, vol. 78 (5-6), 51-56.

Pratama, B. Y., \& Sarno, R. (2015). Personality Classification Based on Twitter Text Using Naive Bayes, KNN and SVM. Knowledge and Information Systems, 170-174.

Pujadayanti, I., Fauzi, M. A., \& Sari, Y. A. (2018). Prediksi Rating Otomatis pada Ulasan Produk Kecantikan dengan Metode Naïve Bayes dan N-gram. Jurnal Pengembangan Teknologi Informasi dan IImu Komputer, 4421-4427.

Rasjid, Z. E., \& Setiawan, R. (2017). Performance Comparison and Optimization of Text Document Classification using k-NNand Naïve Bayes Classification Techniques. Procedia Computer Science, 107112.

Rifauddin, M. (2016). Fenomena Cyberbulying Pada Remaja (Studi Analisis Media Sosial Facebook). Jurnal IImu Perpustakaan, Informasi, dan KearsipanKhizanah Al-Hikmah, 35-44.

Santoso, J., Yuniarno, E. M., \& Hariadi, M. (2015 ). Large Scale Text Classification Using Map Reduce and Naive Bayes Algorithm for Domain Specified Ontology Building. IEEE 2015 7th International Conference on Intelligent Human-Machine Systems and Cybernetics (IHMSC) (pp. 428-232). Hangzhou, China : 2015 7th International Conference on Intelligent Human-Machine Systems and Cybernetics.

Saritas, M. M., \& Yasar, A. (2019). Performance Analysis of ANN and Naive Bayes Classification Algorithm for Data Classification. International Journal of Intelligent Systems and Applications in Engineering, 88-91.

Sastrodikoro W., Y. A., Palit, H. N., \& Justinus Andjarwirawan, J. (2018). Aplikasi Pendeteksi Unsur Hinaan dalam Komentar di Media Sosial Berbahasa Indonesia. Program Studi Teknik Informatika, Fakultas Teknik Industri, Universitas Kristen Petra, vol 1.

Susanto, W., \& Indriyani, L. (2019). Analisis Penerapan Naïve Bayes Untuk Memprediksi Resiko Kredit
Anggota Koperasi Keluarga Guru . JURNAL INFORMATIKA, 262-270.

Tian, L., Yan, Y., \& Huebner, E. S. (2018). The Effects of Cyberbullying and Cybervictimization on Early Adolescents' Mental Health: The Differential Mediating Roles of Perceived Peer Relationship Stress. Cyberpsychology, Behavior, and Social Networking, 1-8.

Wang, S., Jiang, L., \& Li, C. (2015). Adapting naive Bayes tree for text classification. Knowledge and Information Systems, Vol 44; Iss. 1.

Wijanto, M. C. (2015). Sistem Pendeteksi Pengirim Tweet dengan Metode Klasifikasi Naive Bayes. Jurnal Teknik Informatika dan Sistem Informasi , 172-182. 